\title{
DESCRIPTION OF A NEW EULOPHID PARASITIC ON BUCCULATRIX CANADENSISELLA CHAMBERS.
}

\author{
By A. B. Gahan
}

\section{U. S. Department of Agriculture, Bureau of Entomology.}

In order that the name may be available for use in connection with biological notes to be published in a bulletin of the Connecticut Agricultural Experiment Station, the new species of Pleurotropis bred by R. B. Friend is herewith described.

\section{FAMILY EULOPHIDAE}

\section{Subfamily Entedoninoe}

\section{Pleurotropis bucculatricis, new species.}

In Crawford's key to species of Pleurotropis from the United States ${ }^{1}$ this species runs to niger Ashmead but is at once distinguished from that species by its bright metallic green color. Resembles lithocolletidis Ashmead but differs by having the frons above the transferse furrow and also the vertex entirely smooth except for a very faint reticulation within the ocellar traingle. Differs from lithocolletidis also by having the abdomen shorter and more blunt at apex.

Female-Length $1.6 \mathrm{~mm}$. Head, viewed from in front, smooth and polished, the ocellar triangle and a small area on the vertex immediately behind the ocelli faintly reticulated; vertex broadly concave and opaquely sculptured; face below the transverse furrow finely reticulate-punctate, subopaque; inner eyemargins broadly concave; antennal scape slender, about as long as pedicel and two following flagellar joints; pedicel nearly twice as long as thick; three small ring joints; flagellum five jointed, not clavate, the first joint slightly longer and somewhat thicker than pedicel, broadest near middle; second joint ovate, shorter than first and about one and one-half times as long as broad; third joint cup-shaped, as broad as long; fourth joint similar in shape and subequal to the third; fifth joint (club) conical, about

${ }^{1}$ Proc. U. S. Nat. Mus., Vol. 43, 1912, p. 177. 
as long as the fourth but much narrower and terminated by a slender stylus which is approximately half as long as the segment; all flagellar joints moderately hairy; declivous anterior portion of pronotum sculptured like the occiput; dorsal posterior portion smooth and polished; mesoscutum and scutellum rather weakly reticulated, the two depressions on mesoscutum in front of scutellum shallow and smooth; propodeum smooth with the usual two diverging carinæ medially, the lateral folds distinct; pleura for the most part weakly reticulated, the metapleura mostly smooth; forewing devoid of discal cilia from base to near middle of marginal vein and with a wedge-shaped extension of this bare area along the anterior margin to about the apical onefourth of marginal vein; marginal vein much longer than submarginal; stigmal and postmarginal about equal; hind coxæ polished; posterior tarsi with the joints subequal; abdomen about as long as thorax, petiolate, the petiole a little broader than long, closely punctate and opaque; abdomen, exclusive of petiole, elliptical in outline, the basal tergite above occupying more than two-thirds of its length and perfectly smooth, the following tergites very short and weakly shagreened; abdomen beneath distinctly shagreened; ovipositor concealed. General color bright metallic blue or green; occiput and face below transverse groove black with a slight bronzy tinge, a small area above clypeus more or less metallic green and the cheeks bluish black; antennæ metallic blue or green; declivous anterior portion of pronotum, axillæ and pleura bronzy black, the pleura more or less tinted with metallic blue or green in some lights; coxæ metallic green, all femora and tibiæ entirely metallic blue, all tarsi pale with the apical joint black; wings hyaline, venation dark brown; abdominal petiole, entire venter of abdomen and the dorsal segments except the second, bronzy black; second tergite bright metallic blue or green.

Male-Length $1.4 \mathrm{~mm}$. Antennal pedicel not quite twice as long as broad; ring joints very small; flagellum not clavate; first and second flagellar joints subequal, each narrowed into a short next at apex; third joint slightly shorter than the second, ovate, about twice as long as broad; fourth like the third but more broadly truncate at apex; fifth as long as preceding and dis- 
tinctly narrower, conic-ovate, terminating in a stylus approximately one-third as long as the joint; abdomen shorter than the thorax, squarely truncate at apex, the apical segments retracted, petiole slightly longer than broad. Face below the transverse groove sculptured as in the female but metallic green like the front; axillæ, mesopleura, and metapleura nearly concolorous with the mesoscutum. In other respects agreeing with the des. cription of the female.

Type locality.-New Haven, Connecticut.

Type.-Cat. No. 40398 U. S. N. M.

Host.-Bucculatrix canadensisella Chambers.

Six females (one type) and one male (allotype) in U. S. National Museum, reared from the above named host, June 24 to July 9, 1926, by R. B. Friend. Four female paratypes with similar data in the collection of the Connecticut Agricultural Experiment Station, New Haven, Connecticut. 

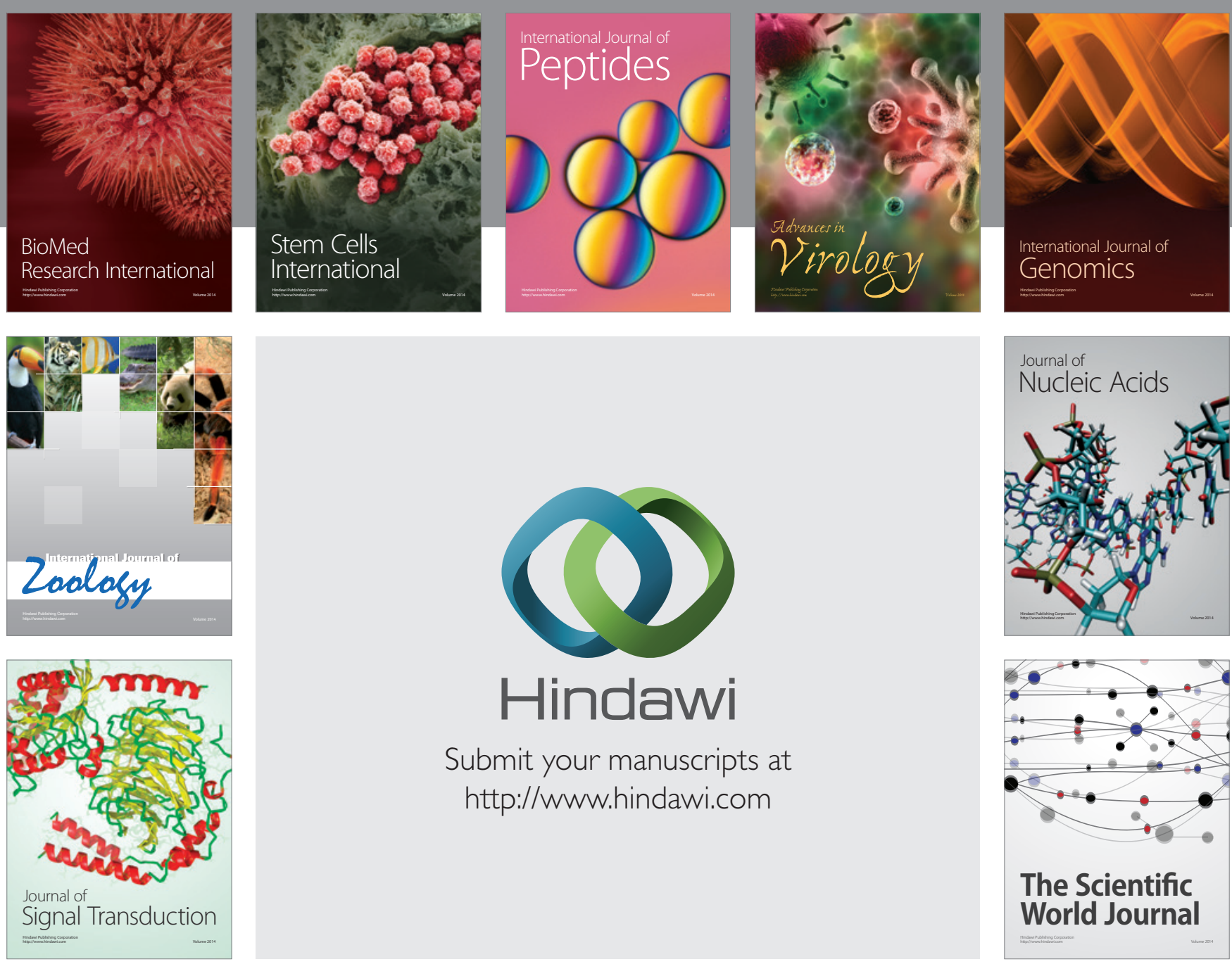

Submit your manuscripts at

http://www.hindawi.com
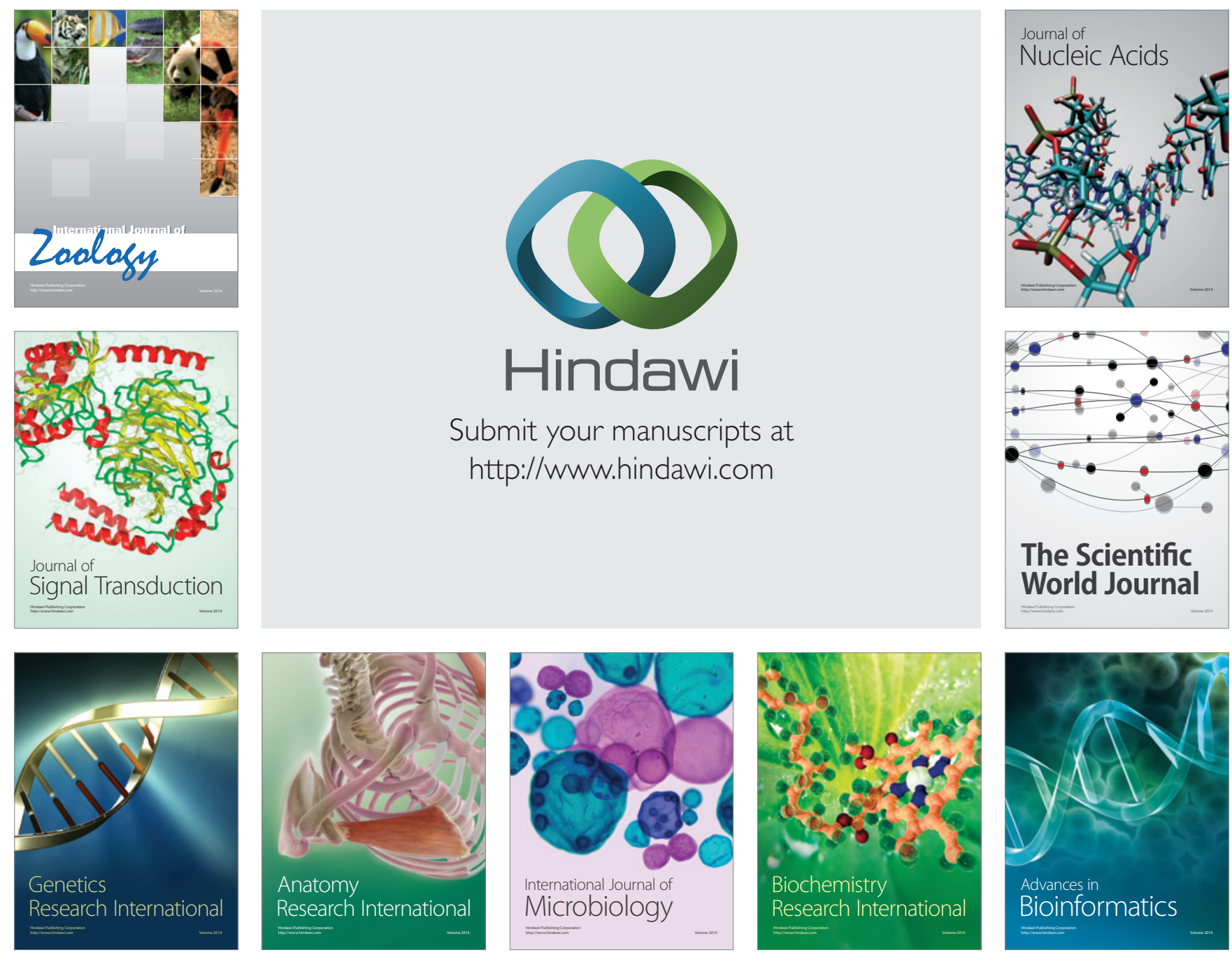

The Scientific World Journal
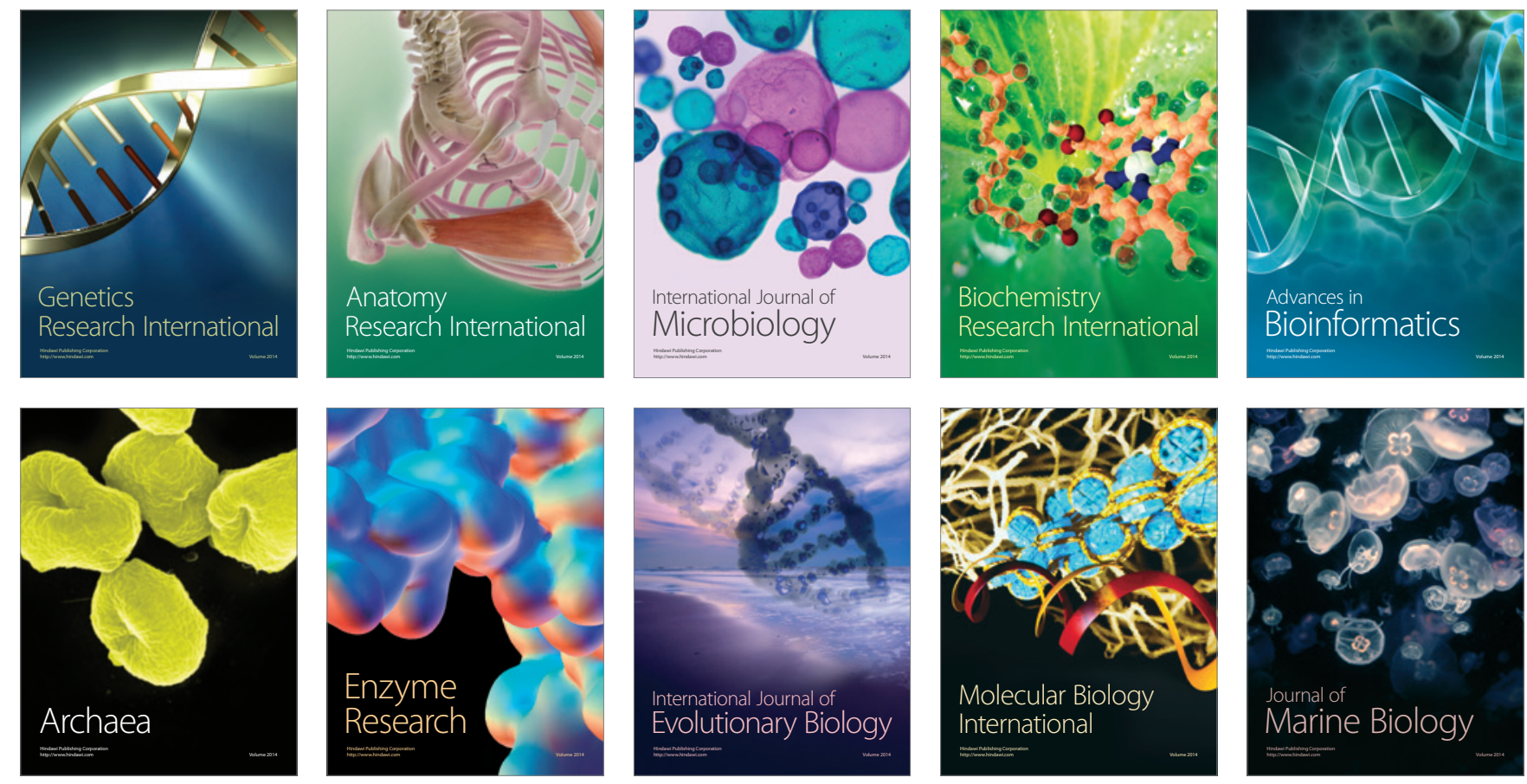